\title{
Megoszlás és membrán-penetráció, mint az ionizáltsági állapot függvénye
}

\author{
NOSZÁL Béla*, MAZÁK Károly, MAZÁKNÉ KRASZNI Márta \\ Semmelweis Egyetem, Gyógyszerészi Kémiai Intézet, Högyes E. u. 9. 1092 Budapest, Magyarország \\ * A közlemény a Magyar Tudományos Akadémia 187. közgyülésén, 2016. május 4-én megtartott előadás \\ szerkesztett változata.
}

\begin{abstract}
Napjainkban az ismert vegyületek száma meghaladja a százmilliót (e közlemény írásakor az Amerikai Kémiai Társaság honlapjának folyamatosan müködő számlálója (https://www.cas.org/) szerint számuk $1,21 \cdot 10^{8}$, de csak kis részüknek alakul úgy a sorsa, hogy hatóanyag váljék belőlük. A hatóanyagok száma az Európai Gyógyszerkönyv 8.7-es kiadásában 1151, tehát öt nagyságrenddel kevesebb, mint az ismert vegyületeké.
\end{abstract}

Ennek legföbb oka, hogy egy vegyületnek számos követelményt kell teljesítenie ahhoz, hogy hatóanyaggá váljon. A hatóanyaggá válás molekuláris sine qua non-ja egyrészt a célmolekulához kötődés szelektív és hatás-kiváltó képessége (farmakodinámiás követelmény), másrészt magához a célmolekulához való eljutás. Ez utóbbi, farmakokinetikai követelmény magában foglalja mind a vizes (vér, nyál, gyomor-, bélnedv, stb.), mind a lipoid biológiai közegekben (pl. központi idegrendszerben) való oldódást, valamint a különböző membránokon való áthatolást.

A sejtmembránok keresztmetszetükben korántsem egyenletes polaritásúak. Míg a membrán felszínén a negatív töltésű foszfát csoportok mellett gyakran elöfordulnak permanensen kationos (pl. kolin), vagy pH-függő módon pozitív töltéssel rendelkezö csoportok (ez utóbbiak valamilyen aminocsoportok) is, addig a membrán belsejében helyet foglaló hosszú szénláncok erősen hidrofób közeget alakítanak ki. A membrán egyes részeinek polaritása jól jellemezhető az ott uralkodó dielektromos állandó (relatív permittivitás) számértékével. Míg ez a membránok extra- vagy intracelluláris felszínén a vizes közegre jellemző 78-as érték körül van, addig a membrán belsejében akár 2-re is lecsökkenhet, ami megegyezik a legkevésbé poláros szerves oldószerek, köztük az alkánok és a dioxán dielektromos állandójával.

A hatóanyagok farmakokinetikai tulajdonságait, de magát a célmolekulához való kötődést is döntő mértékben befolyásolja azok ionizáltsági állapota. Míg a láz-, fájdalom-, és gyulladás-csökkentő, valamint vérlemezkeaggregációt gátló acetil-szalicilsav csak két fajta ionizáltsági állapotban fordulhat elő (töltésmentes sav vagy deprotonált anion), addig több protonálható csoporttal rendelkező molekulák esetében számos különböző mértékben protonált, így eltérő töltéssel rendelkező forma is előfordul.

Egyetlen protonálható csoporttal rendelkező molekulák esetén a sav-bázis tulajdonságokat egyértelmúen jellemzi a molekula protonálódási makroállandója. Tízes alapú logaritmusának számértéke (log $K$ ) ebben az esetben megegyezik a protonált forma disszociációs állandójának negatív tízes alapú logaritmusával ( $\left.\mathrm{p} K_{\mathrm{s}}, \mathrm{p} K_{\mathrm{a}}\right)$. Általánosságban, ha $\mathrm{L}$ jelenti a molekula legbázikusabb formáját, valamint $K_{\mathrm{i}}$ és $\beta_{\mathrm{i}}$ az i-szer protonált forma keletkezését jellemző lépcsőzetes és kumulatív makroállandót, az összefüggések a következő alakot öltik:

$$
\begin{aligned}
& \mathrm{LH}_{\mathrm{i}-1}+\mathrm{H}^{+} \rightleftharpoons \mathrm{LH}_{\mathrm{i}} \\
& \mathrm{K}_{\mathrm{i}}=\frac{\left[\mathrm{LH}_{\mathrm{i}}\right]}{\left[\mathrm{LH}_{\mathrm{i}-1}\right]\left[\mathrm{H}^{+}\right]} \\
& \mathrm{L}+\mathrm{iH}^{-} \rightleftharpoons \mathrm{LH}_{\mathrm{i}} \\
& \beta_{\mathrm{i}}=\frac{\left[\mathrm{LH}_{\mathrm{i}}\right]}{[\mathrm{L}]\left[\mathrm{H}^{+}\right]^{\mathrm{i}}}=\prod_{\mathrm{j}=1}^{\mathrm{i}} \mathrm{K}_{\mathrm{j}}
\end{aligned}
$$

Az egyszerübb és általánosabb jelölés kedvéért a részecskék töltését a fenti egyenletekben a hidrogénion kivételével elhagytuk. A makroállandóknak csupán a felsorolása is táblázatos könyvek (illetve az utóbbi időben számítógépes adatbázisok) köteteit tölti $\mathrm{meg}^{1-3}$ és a gyógyszerkémiai tankönyvek fontos, vagy éppen egyetlen táblázatos melléklete a hatóanyagok protonálódási állandóit tartalmazza. ${ }^{4}$

A makroállandók hasznosak, ha a különböző mértékben protonált részecskék koncentrációjának kiszámítása a cél a $\mathrm{pH}$ függvényében, vagy ha a molekula izoelektromos pontjának illetve átlagos töltésének meghatározása a feladat. Ugyanakkor, a makroállandók igen fontos korlátja, hogy a molekula egészét jellemzik, az egyedi funkciós csoportok bázicitásáról azonban nem nyújtanak információt. A kísérletileg meghatározott és publikált egyensúlyi állandók döntő többsége makroállandó, ezért a makro- (más néven makroszkopikus) jelző használata rendszerint el is marad.

Többcsoportos molekulák egyes funkciós csoportjainak sav-bázis tulajdonságai csoportállandókkal, mikro- állandókkal vagy szubmikroállandókkal jellemezhetők. ${ }^{5}$ Ezen szubmolekuláris szintü egyensúlyi állandókban hordozott szerkezeti információ a fenti sorrendben egyre részletesebb. A csoportállandók az egyes funkciós csoportok bázicitását tükrözik, de a molekula többi részének protonáltsági állapotát figyelmen kívül hagyják, és csak speciális esetekben alkalmazhatók. $^{6}$ A mikroállandók (mikroszkopikus protonálódási állandók) az egyes funkciós csoportok bázicitását jellemzik a molekula összes többi csoportjának bizonyos, meghatározott protonáltsági állapotában. ${ }^{7}$ A szubmikroállandók mikroállandón felüli információja az, hogy még a molekula konformációs (rotációs) állapotát is tükrözik. ${ }^{8}$ 
$\mathrm{Az}$ 1. ábra az egyik legismertebb hatóanyag, a morfin mikroegyensúlyi sémáját mutatja be. A morfin a fájdalomcsillapító hatása mellett rendelkezik légzés- és köhögésgátló, pupilla-szükítő, hipotonizáló, szorulás-keltő és euforizáló hatással is. Az ábrán látható a 4 mikrorészecske (a molekulának négyféle protonáltsági állapotú formája), a 4 mikroállandó $\left(k^{\mathrm{N}}, k^{\mathrm{O}}, k^{\mathrm{N}}, k_{\mathrm{O}}^{\mathrm{O}}\right)$ és a 2 lépcsőzetes makroállandó $\left(K_{1}, K_{2}\right)$. Az $\mathrm{N}$ és $\mathrm{O}$ indexek a nitrogén és oxigén atomok protonálódására utalnak. A $k$ mikroállandó felső indexe az adott folyamatban protonálódó funkciós csoportot jelöli, az (esetleges) alsó index pedig a már protonált csoportot.

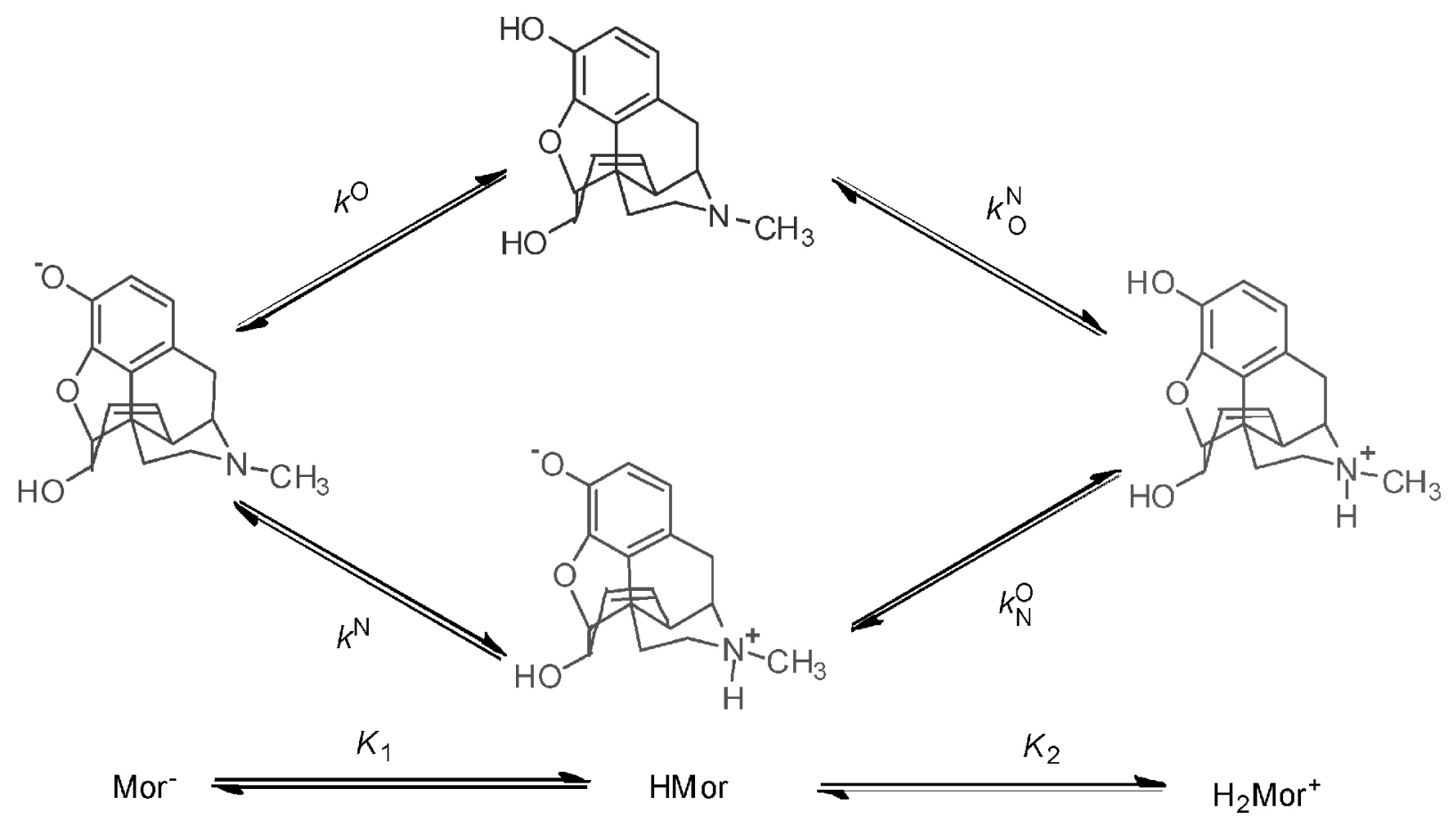

1. ábra. A morfin mikroegyensúlyi sémája.

A makro- és mikroállandók közötti kapcsolat kétcsoportos molekulákra a következő ${ }^{7}$ :

$$
\begin{gathered}
\beta_{1}=K_{1}=k^{\mathrm{N}}+k^{\mathrm{O}} \\
\beta_{2}=K_{1} K_{2}=k^{\mathrm{N}} k_{\mathrm{N}}^{\mathrm{O}}=k^{\mathrm{O}} k_{\mathrm{O}}^{\mathrm{N}}
\end{gathered}
$$

Amint látható, az egyszeresen protonált forma (HMor) kétféle módon keletkezhet az anionból: a proton vagy a fenolát-, vagy az aminocsoportra kerül. Az azonos összetételü töltésmentes és ikerionos mikrorészecskéket protonáltsági izomereknek hívjuk. A protonálódási folyamatok a legtöbb oldószerben pillanatszerüen gyorsak, így a mikrorészecskék egymásba pillanatszerüen átalakulnak. Ezért a protonáltsági izomerek mindig együtt fordulnak elő az oldatban, és a jelenleg ismert elválasztástechnikai módszerekkel elkülöníthetetlenek. Tovább nehezíti meghatározásukat, hogy koncentrációarányuk a pH-tól független:

$$
\frac{\left[\mathrm{HMor}_{-}^{+}\right]}{\left[\mathrm{HMor}_{0}^{6}\right]}=\frac{k^{\mathrm{N}}\left[\mathrm{Mor}^{-}\right]\left[\mathrm{H}^{+}\right]}{k^{\mathrm{O}}\left[\mathrm{Mor}^{-}\right]\left[\mathrm{H}^{+}\right]}=\frac{k^{\mathrm{N}}}{k^{\mathrm{O}}}
$$

Ezért a protonáltsági izomerek individuális spektroszkópiai, kinetikai jellemzői közvetlenül nem tanulmányozhatók. ${ }^{5}$
Mivel a biomolekulák specifikus kölcsönhatásai a megfelelő finomszerkezetü (protonáltsági állapotú és konformációjú) mikroformáik révén valósulnak meg, és a specifikus biokémiai reakciókban nem mindig a domináns mikrorészecske a reaktív ${ }^{9-13}$, szükség van valamennyi mikrorészecske koncentrációjának kiszámítására, ami az összes mikroállandó meghatározását igényli. A mikrorészecskék koncentrációinak és protonálódási egyensúlyi állandóinak meghatározását 1986 óta definíciószerűen mikrospeciációnak nevezzük. ${ }^{14}$

A morfin részecske-eloszlása a 2 . ábrán látható. ${ }^{15}$ Bármely $\mathrm{pH}-\mathrm{n}$ a töltésmentes részecske koncentrációja 2,9-szerese az ikerionosénak.

A három protonálható csoporttal rendelkező molekulák (pl. a $\beta$-laktám antibiotikum amoxicillin) esetén a mikro- részecskék száma 8, míg a négycsoportosak (pl. a Parkinson-kór terápiájában használt levodopa) már 16 mikrorészecskével rendelkeznek. Azonban bármennyi is a mikrorészecskék száma, ezek közül mindig csak egyetlen lesz töltésmentes, ennek protonáltsági izomerjei csak „bruttó semlegesek”, valójában különböző módokon ikerionos formák. 


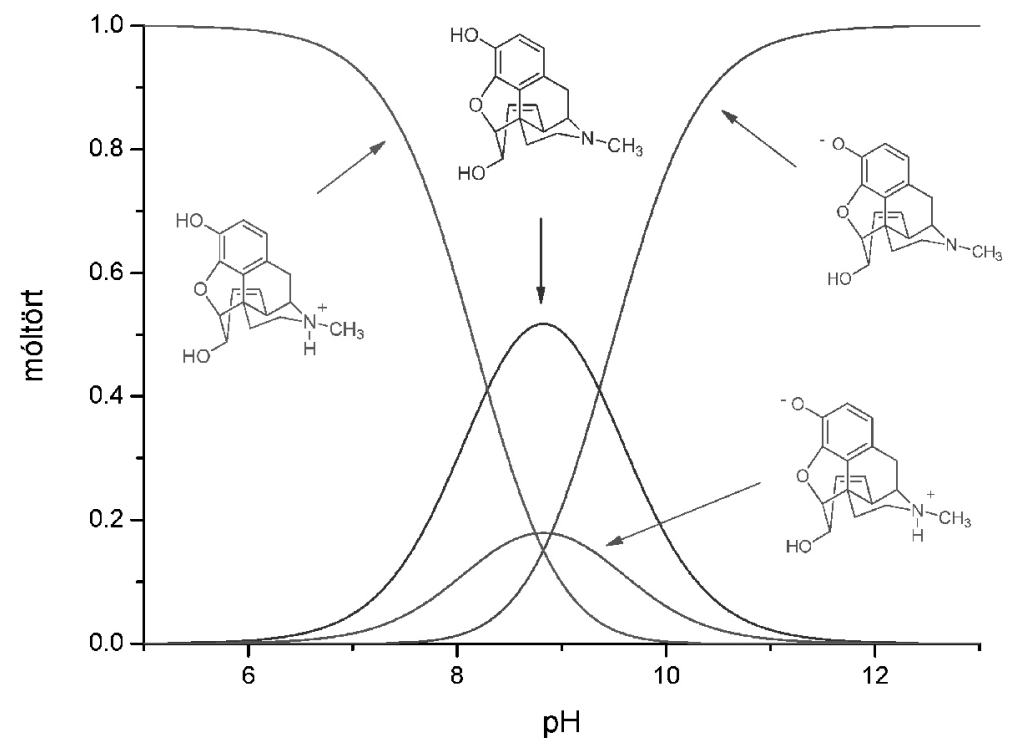

2. ábra. A morfin részecske-eloszlása

A molekulák töltése, és a töltés molekulán belüli eloszlása alapvetően meghatároz számos, a farmakokinetikai tulajdonságokkal összefüggő fizikai-kémiai paramétert, így a lipofilitást, oldhatóságot és a permeabilitást.

Lipofilitáson tágabb értelemben egy anyag zsírkedvelő jellegének mértékét, zsírszerű anyagokban való oldódási hajlamát értjük. Gyógyszermolekulák esetében a lipofilitás az egyik legfontosabb fizikai-kémiai tulajdonság, amely elsősorban a hatás farmakokinetikai fázisában játszik szerepet, és a membránpenetrációra való készséget jelzi. ${ }^{16-17}$

A membránpenetrációban résztvevő részecskék azonosítása a gyógyszerkutatás egyik legfontosabb általános kérdése. Egészen az utóbbi évekig az volt az uralkodó álláspont, hogy a molekulát a töltésmentes formája viszi át a membránon, és ez fordul elő a központi idegrendszerben. Ezzel a nézettel kapcsolatban azonban egyre több kétely is felmerült. Például, a H1 hisztamin-receptor antagonista, különböző allergiák kezelésére használt vegyületek egyik mellékhatása az aluszékonyság, melynek feltétele a perifériásnak szánt hatóanyag bejutása a lipoid központi idegrendszerbe. Annak érdekében, hogy ezt a mellékhatást kiküszöböljék, permanensen ikerionos szerkezetü vegyületeket is forgalomba hoztak, például az akrivasztint, cetirizint és több egyebet, de a várakozásokkal ellentétben - ezeknél is fennmaradt ez a nem kívánt mellékhatás, ami annak bizonyítéka, hogy a hatóanyag a központi idegrendszerbe kerül.

Nagy csoportszámú molekulák (pl. a különböző fehérjehormonok és a napjainkban egyre inkább terjedő makromolekuláris, bioszimiláris gyógyszerek) esetében pedig a töltésmentes forma koncentrációja gyakran nagyon alacsony, így nehezen képzelhető el, hogy csupán ez járul hozzá a membránpenetrációhoz.

Azt bebizonyítani, hogy melyik mikrorészecske hatol át a membránon, súlyos nehézségekbe ütközik, hiszen a protonáltsági izomerek - mint föntebb bemutattuk - mindig együtt fordulnak elő koncentráció-arányuk állandó. Viszont megfelelő módszerekkel meg lehet azt határozni, hogy az egyes mikrorészecskék milyen mértékben járulnak hozzá a molekula adott pH-ra jellemző lipofilitásához. ${ }^{18}$

A lipofilitás számszerü jellemzésére a gyógyszerkémiai szerkezethatás-összefüggésekben az oktanol/víz megoszlási hányados logaritmusa $(\log P)$ vált általánosan elfogadottá. ${ }^{19}$ Egy anyag megoszlási hányadosán két egymással nem elegyedő oldószerben, azonos molekuláris állapotban (protonáltság, asszociáció mértéke, tautomer formák) mért egyensúlyi koncentrációjának arányát értjük. Konvencionálisan a szerves fázisban mérhető koncentráció a számlálóban szerepel, így a megoszlási hányados minél nagyobb számérték, annál nagyobb lipofilitást jelöl. A megoszlás számos kromatográfiás és nagy teljesítőképességü osztályozó (high throughput screening) módszer elméleti hátterét is képezi.

Ionizálható vegyületek megoszlását jelentős mértékben befolyásolják az oldatban lévő egyéb ionok, melyek megszabják az oldat ionerősségét, és ionpárt képezhetnek a vegyület ionizált formájával/formáival. ${ }^{20-22}$ Semleges molekulák megoszlási hányadosa a legtöbb megosztó rendszerben nagyságrendekkel nagyobb, mint ezen molekulák ionizált formáié.

Protikus molekuláknál az adott pH mellett meghatározható megoszlási hányados (disztribúciós koefficiens) kialakításában többféle részecskének van szerepe. E részecskék mindegyikének van saját, pH-független megoszlási hányadosa, melyek móltörtjükkel súlyozva adják az adott pH-n meghatározható megoszlási hányadost.

$$
D=\Sigma x_{\mathrm{i}} p_{\mathrm{i}}
$$

ahol $x_{\mathrm{i}}$ az egyes mikrorészecskék relatív koncentrációja a vizes fázisban, $p_{\mathrm{i}}$ pedig azok megoszlási hányadosa. A látszólagos megoszlási hányados $\mathrm{pH}$-függése (a lipofilitás- $\mathrm{pH}$ profil) 
nélkülözhetetlen a gyógyszer-molekulák szervezetbeni sorsának megértéséhez. A lipofilitás-pH profil ismerete hasznos a gyógyszeranalitikában, valamint növényi anyagok extrakciójában is, a pH optimálásához. Egyértékü savak és bázisok esetén a disztribúciós hányados abban a pH-tartományban maximális, ahol a töltésmentes forma koncentrációja meghaladja az ionos formáét. Ikerionos vegyületek lipofilitás profilja mutathat maximumot és minimumot is az ikerionos forma lipofilitásától és a protonáltsági izomerek relatív koncentrációjától függően. ${ }^{23}$

A 3. ábra a morfin lipofilitás-pH profilját mutatja be vastag, fekete vonallal, amely alatt különböző színekkel az egyes mikrorészecskék hozzájárulása látható. ${ }^{15} \mathrm{~A}$ töltésmentes részecske koncentrációja 2,9-szerese az ikerionosénak, mikroszkopikus lipofilitása 1070-szerese, így hozzájárulása a morfin molekula szerves fázisba (membránba) való átviteléhez 3090-szeresen haladja meg az ikerionosét. Viszont savas, 5,3-nál alacsonyabb pH-jú közegben (így a gyomorban is) már a kationos forma hozzájárulása a meghatározó a lipofilitáshoz. Az anionos forma csak igen lúgos közegben, 12,3-nél magasabb pH-nál jut domináns pozícióba.

$\mathrm{Az}$ agyi vérkeringés-fokozó vinpocetin, a kis télizöld meténgböl (Vinca minor) kinyerhető vinkamin félszintetikus származéka egy pentaciklusos eburnánvázat tartalmazó alkaloid. Fő metabolitja a cisz-apovinkaminsav, amelynek lipofilitás-pH profilja a 4. ábrán látható. ${ }^{24} \mathrm{Az} \mathrm{U}$-alakú profil a morfinnal ellentétben minimumot mutat az izoelektromos pont környékén.

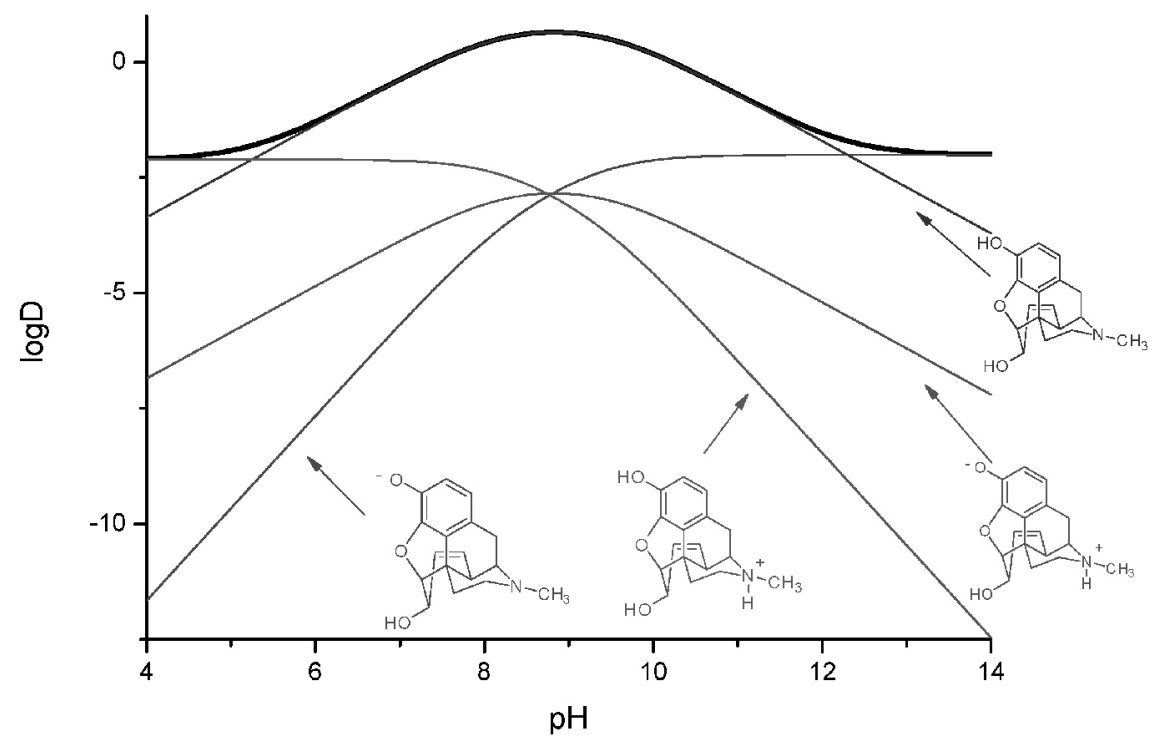

3. ábra. A morfin lipofilitás-pH profilja

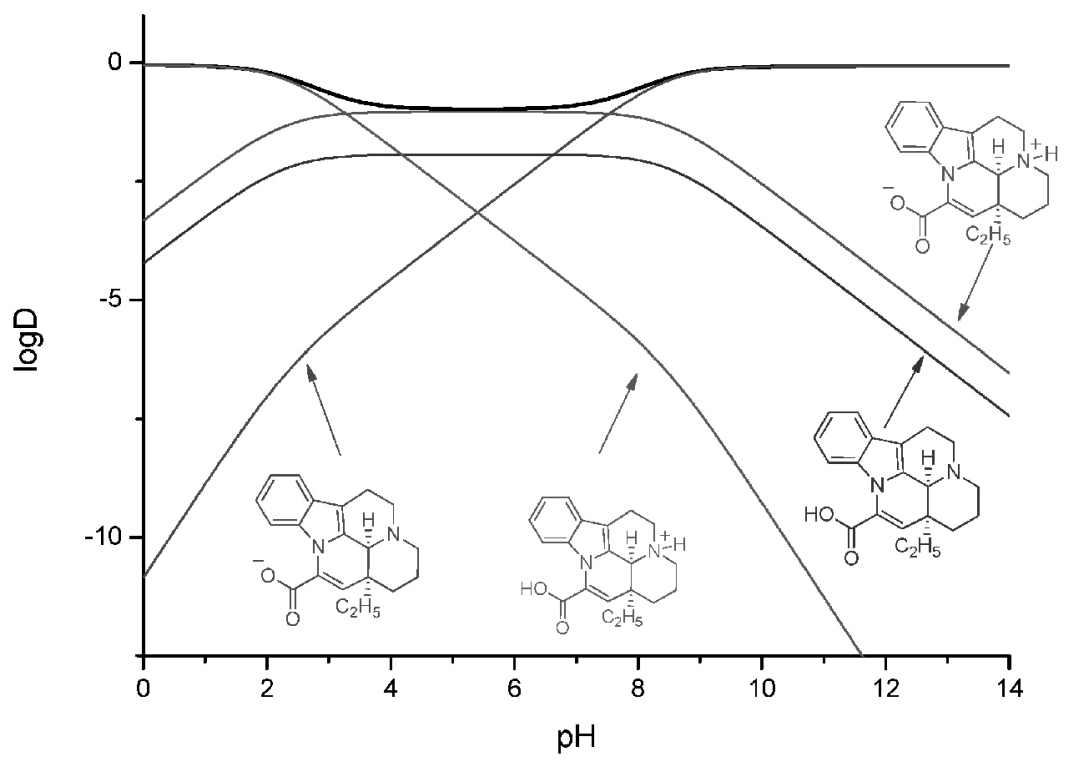

4. ábra. A cisz-apovinkaminsav lipofilitás-pH profilja

123. évfolyam, 1. szám, 2017. 
Bár a töltésmentes protonáltsági izomer $30 \quad$ 900-szor lipofilebb, mint az ikerionos, az utóbbi 245 000-szer gyakrabban fordul elő az oldatban, így végül hozzájárulása a látszólagos megoszlási hányadoshoz 7,9-szer meghaladja a töltésmentes formáét.

A pajzsmirigy egyik hormonja, a tiroxin szerepet játszik az agy fejlődésében, hatására fokozódik a szívműködés, légzés és a metabolikus aktivitás. A molekula már három protonálható csoporttal rendelkezik. A hat legnagyobb koncentrációban előforduló mikrorészecskéjének hozzájárulása a lipofilitás-pH profilhoz az 5. ábrán látható. ${ }^{25}$

A molekula lipofilitását alapvetően a jóddal szubsztituált benzolgyürűk határozzák meg, ezért a töltésmentes részecske mindössze 2,4-szer lipofilebb, mint ikerionos izomerje. Mivel azonban az ikerionos részecske koncentrációja 35 000-szerese a töltésmentesének, a molekula szerves fázisba jutásához 14500 : 1 arányban járulnak hozzá az ikerionos ill. töltésmentes részecskék.

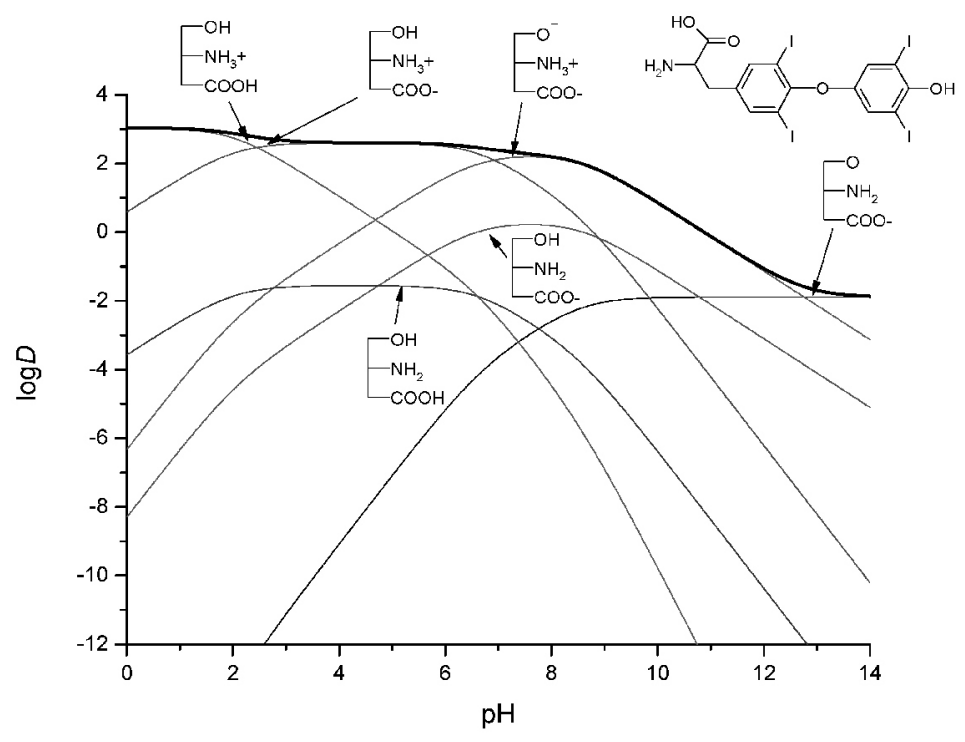

5. ábra. A tiroxin lipofilitás-pH profilja

A gyógyszerek membránpenetrációját azonban nemcsak az ionizáltsági, hanem a konformációs állapot is befolyásolja. A konformer-specifikus megoszlási hányadosok meghatározásának igénye az irodalomban már 1970-ben megjelent, de megfelelő összefüggések és kiértékelő módszerek hiányában 35 éven át nem valósult meg. ${ }^{26} \mathrm{Az}$ első konformer- specifikus megoszlási hányadosokat oktanol/víz rendszerben az amfetaminra és az antiasztmatikus hatású, de egyben izomtömeg-fokozóként doppingszernek is minősülö klenbuterolra határozták meg. ${ }^{27}$

A konformer-specifikus megoszlási hányadosok meghatározását megnehezítette, hogy az egyes forgási izomerek mindössze nagyjából $10^{-9} \mathrm{sec}$ egyedi élettartamúak, és egymástól elválaszthatatlanok. A klenbuterol rotamerjeit a 6 . ábra mutatja.

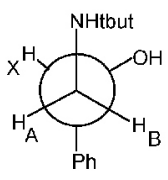

$t$

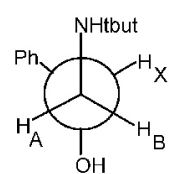

g

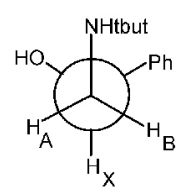

h
6. ábra. A klenbuterol rotamerjei.

Az aminosavak rotamerjeinek Martin-féle jelölésmódja szerint $^{28} t$ jelet kap az a rotamer, amelyben a két legnagyobb térkitöltésü csoport, a karboxilát és az R csoport transz (antiperiplanáris) térállású. A $g$ és $h$ rotamerekben ezek a csoportok gauche (szinklinális) helyzetüek. A $h$ rotamer a három nagy térkitöltésü csoportot, illetve a három hidrogént egymás közvetlen szomszédságában tartalmazza, így ez a konformer a sztérikusan legkedvezőtlenebb elrendeződésü (hindered).

A klenbuterolnak és rotamerjeinek megoszlási sémája a log $P$ értékekkel a 7. ábrán látható.

A nagy térkitöltésű NHtbut és fenil csoportok taszítása következtében mindkét fázisban a $t$ rotamer dominál. A konformer-specifikus megoszlási hányadosok nagy különbségeket mutatnak ( $t$ rotamer 740, $g$ rotamer 140). A legnagyobb $p$ érték a $t$ rotamerhez tartozik, mivel a fenil csoport jól hozzáférhető a szolvatáló oktanolmolekulák számára. Itt a két poláris csoport egymás közelében helyezkedik el, így lehetőségük van hidrogén-híd kötés kialakítására. Ez az intramolekuláris kölcsönhatás kedvezőtlenül hat a molekula hidratálódására, elősegítve ezzel az apoláris szolvatációt. A legalacsonyabb megoszlási hányados a $g$ rotamer-hez tartozik, mert ebben a víz jól tudja szolvatálni az egyedül álló hidroxilcsoportot. A membránba való belépéshez a klenbuterol $t$ konformerje a kedvező forma, míg a membránból való kilépéshez a $g$ konformer. Ezek az első rotamer-specifikus megoszlási hányadosok, és az első kísérleti evidencia arra, hogy egy molekula különböző konformációs állapotban lép be a membránba illetve lép ki a membránból. 


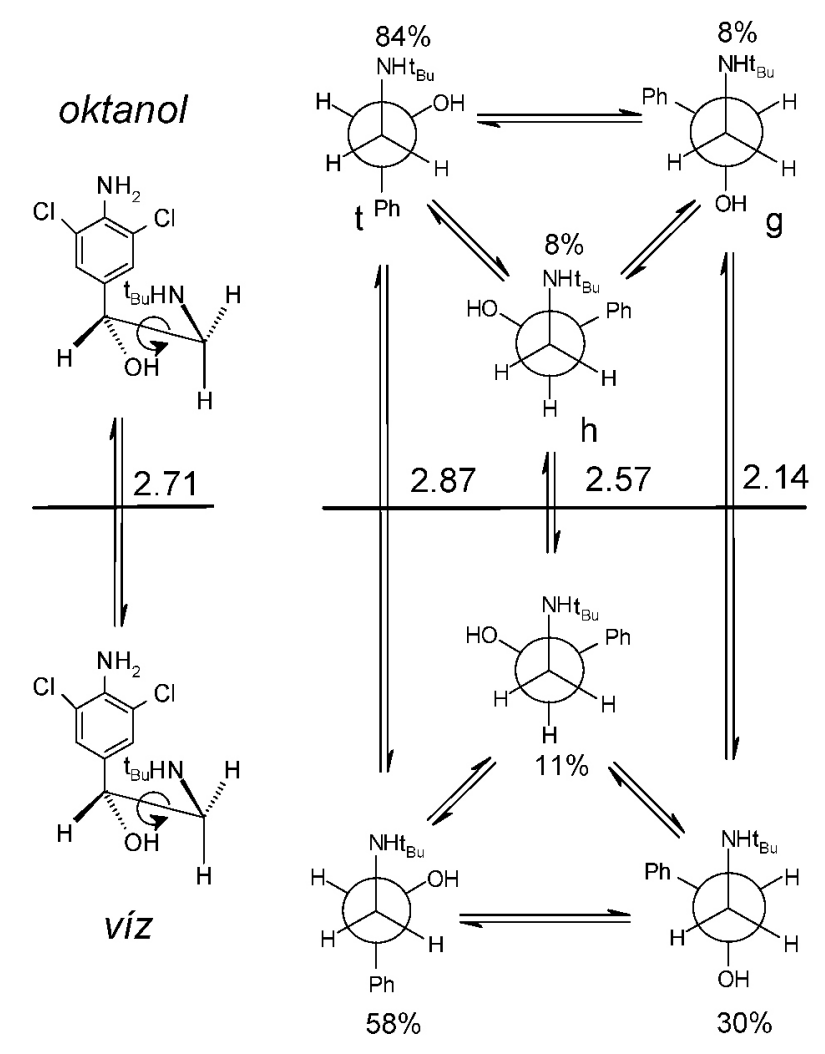

7. ábra. A klenbuterol és rotamerjeinek megoszlási sémája a rotamerek százalékos eloszlásával és a klenbuterol egészének, valamint az egyes rotamerek megoszlási hányadosának a log értékeivel.

A fentiekből az alábbi két fontos következtetést lehet levonni:

1) A különböző ionizáltságú állapotban lévő részecskék közül a hatóanyagot dominánsan az viszi át a membránon, melynek pH-függő koncentrációja és egyedi lipofilitása a legnagyobb szorzatot adja. Ez pH-tartományonként más-más részecske lehet, és nem feltétlenül a töltésmentes részecske.

2) A membránba preferáltan belépő és onnan kilépő részecskék jellemzően nem azonosak.

Köszönetnyilvánítás: A jelen dolgozat alapját képező munkákat támogatták a TÁMOP 4.2.1.B-09/1/KMR és OTKA T 73804 pályázatok.

\section{Hivatkozások}

1. Sillén, L. G.; Martell, A. E. Stability constants of metal-ion complexes. Vol. I. 1964, Vol. II. 1971.

2. Smith, R. M.; Martell, A. E. Critical stability constants II., IV. Plenum, New York, London, 1975, 1976.

3. Serjeant, E. P.; Dempsey, B. Ionisation constants of organic acids in aqueous solution. Pergamon, Oxford, 1979.

4. Wilson and Gisvold's Textbook of organic medicinal and pharmaceutical chemistry. 9th edition. J. B. Lippincott Company, Philadelphia. 1991, 877-881.
5. Noszál, B. In Burger, K. (ed.), Biocoordination chemistry: coordination equilibria in biologically active systems. Ellis Horwood, Chichester. 1990, 18-55.

6. Noszál, B.. J. Phys. Chem. 1986, 90, 4104-4110. https://doi.org/10.1021/j100408a053

7. Bjerrum, N. Z. Phys. Chem. 1923, 106, 219-242.

8. Kraszni, M.; Kökösi, J.; Noszál, B. J. Chem. Soc., Perkin Trans. 2. 2002, 914-917. https://doi.org/10.1039/b200846g

9. Noszál, B.; Scheller-Krattiger, V.; Martin, R. B. J. Am. Chem. Soc. 1982, 104, 1078-1081. https://doi.org/10.1021/ja00368a027

10. Noszál, B.; Rabenstein, D. L. J. Phys. Chem. 1991, 95, 4761-4765. https://doi.org/10.1021/j100165a031

11. Szakács, Z., Noszál, B. Electrophoresis, 2006, 27, 3399-3409. https://doi.org/10.1002/elps.200600128

12. Orgován, G.; Tihanyi, K.; Noszál, B. J. Pharm. Biomed. Anal. 2009, 50, 718-723. https://doi.org/10.1016/j.jpba.2009.05.036

13. Tóth, G.; Baska, F.; Schretner, A.; Rácz, Á.; Noszál, B. Eur. Biophys. J. 2013, 42, 721-730.

https://doi.org/10.1007/s00249-013-0921-1

14. Noszál, B.. J. Phys. Chem. 1986, 90, 6345-6349. https://doi.org/10.1021/j100281a056

15. Mazák, K.; Noszál, B. Eur. J. Pharm. Sci. 2012, 45, 205-210. https://doi.org/10.1016/j.ejps.2011.11.007

16. Pliska, V.; Testa, B.; van de Waterbeemd, H. (ed). Lipophilicity in Drug Action And Toxicology. VCH publishers, Weinheim, 1996.

17. Testa, B.; van de Waterbeemd, H.; Folkers, G.; Guy R. (ed). Pharmacokinetic Optimization in Drug Research. WILEY-VCH publishers, Zürich 2001.

18. Mazák, K.; Noszál, B. Eur. J. Pharm. Sci. 2014, 62, 96-104. https://doi.org/10.1016/j.ejps.2014.05.017

19. Hansch, C.; Wermuth, C.G., Koga, N., König, H. (ed.), Medicinal chemistry for the $21^{\text {st }}$ century, Metcalf Blackwell, Oxford, 1994.

20. Takács-Novák, K.; Szász, Gy. Pharm. Res. 1999, 16, 1633-1638 . https://doi.org/10.1023/A:1018977225919

21. Bouchard, G.; Carrupt, P.; Testa, B. ; Gobry, V.; Girault, H. Pharm. Res. 2001, 18, 702-708.

https://doi.org/10.1023/A:1011001914685

22. Reymond, F.; Gobry, V.; Bouchard, G.; Girault, H.; in Testa, B.; van de Waterbeemd, H.; Folkers, G.; Guy R. (ed), Pharmacokinetic Optimization in Drug Research. WILEY-VCH publishers, Zürich, 2001, 327-349. https://doi.org/10.1002/9783906390437.ch19

23. Pagliara, A.; Carrupt, P.; Caron, G.; Gaillard, P.; Testa, B. Chem. Rev. 1997, 97, 3385-3400. https://doi.org/10.1021/cr9601019

24. Mazák, K.; Noszál, B. J. Med. Chem. 2012, 55, 6942-6947. https://doi.org/10.1021/jm3007992

25. Mazák, K.; Tóth, G.; Kökösi, J.; Noszál, B. Eur. J. Pharm. Sci. 2012, 47, 921-925. https://doi.org/10.1016/j.ejps.2012.09.009

26. Noszál, B.; Kraszni, M. J. Phys. Chem. B 2002, 106, 1066-1068. https://doi.org/10.1021/jp013823z

27. Kraszni, M.; Bányai, I.; Noszál, B. J. Med. Chem. 2003, 46, 2241-2245. https://doi.org/10.1021/jm030767c

28. Martin, R. B.; Mathur, R. J. Am. Chem. Soc. 1965, 87, 1065. https://doi.org/10.1021/ja01083a023 


\section{Partition and membrane-penetration as a function of ionization state}

Membrane penetration and other partitions of bio- and drug molecules in living systems are controlled by a few molecular properties, such as their state of ionization, and the concomitant physico-chemical parameters. The eminent ones of these parameters are species-specific basicity and lipophilicity.

Physico-chemical properties can be characterized at different levels. Macroscopic parameters are the most widespread ones, but they only characterize the molecule as a whole, offering no insight into submolecular (site-specific or moiety-specific) processes and interactions. For site-specific information, one must determine submolecular species-specific parameters, which can be defined at the so-called microscopic or submicroscopic level. The microscopic description specifies both the site of protonation and the protonation states of all functional sites in a molecule. The submicroscopic description provides even more detail, defining the rotational or conformational status of a given species during a physico-chemical process.

The acid-base properties of a molecule are among the most fundamental ones for drug action. However, they are often overlooked in drug design unless it has been established that a certain ionization state is required for activity. However, apart from the preference for a certain ionization state for the pharmacodynamic activity, all pharmacokinetic properties, namely absorption, distribution, metabolism, excretion and toxicity are influenced by the ionization state (the charge and its intramolecular distribution) under varying $\mathrm{pH}$ conditions. This actually means that pharmacodynamically active drug candidate molecules with unfavourable pharmacokinetic properties cannot even reach their intended target molecule. Consideration of acid-base properties in conjunction with other molecular properties is of great significance and has the potential to be used to further improve the efficiency of drug discovery. Acid-base properties also play a very significant role in the formulation of a drug substance for both oral and intravenous dosage forms.

The isomeric forms of protonation microspecies are coexisting ones: they always occur in the presence of each other, due to their fast, continuous interconversion (Fig.1). They therefore produce composite analytical signals; however they act individually in structure-controlled, specific biochemical processes.

The aim of microspeciation is to determine the concentrations of microspecies at any $\mathrm{pH}$ value. The determination of microconstants allows the construction of microspecies distribution diagrams. These diagrams characterize the relative concentration of microspecies over a wide $\mathrm{pH}$ interval (Fig.2).

Lipophilicity is a molecular property of immense importance in pharmacy, bio-, and medicinal chemistry, expressing the affinity of the molecule for a lipophilic environment. In order to quantify lipophilicity, the commonly accepted parameter is log $P$, the logarithm of the partition coefficient, the concentration ratio of a solute present in a single electrical state and in equilibrium between two immiscible solvents.

The organic solvent of choice is usually octanol. When more than one electrical species are present in solution, the observed ratio of concentrations is the distribution coefficient, which takes into account the intrinsic species-specific lipophilicity of the various electrical species present, and their mole fractions in the aqueous phase.

The lipophilicity of ionizable drugs and solutes has been underrepresented in the literature, and the role of charged microspecies in membrane penetration processes has been underestimated until recently, due mainly to the lack of reliable methods to determine the partition coefficients of the ionic forms. This is especially true for ionization/protonation isomers, such as the zwitterionic and non-charged forms of amphoteric compounds.

Our recent studies enabled the determination of previously inaccessible species-specific partition coefficients for coexisting, inseparable protonation isomers. This thorough insight provides explanation why some drugs unexpectedly get into the central nervous system and sheds some light on the submolecular mechanism of pharmacokinetic processes.

The contribution of the various ionic forms to the overall partition can now be quantified and represented on the lipophilicity-pH profile, exemplified here on morphine, cis-apovincaminic acid and thyroxine.

For morphine, the (in)famous opiate alkaloid, in addition to the much higher lipophilicity of the non-charged form, there are approximately three times as many non-charged microspecies than zwitterionic ones, irrespective of the $\mathrm{pH}$, ensuring that the contribution of the non-charged form to the overall lipophilicity is the dominant factor (Fig.3).

Vinpocetine is a valuable cardiovascular agent in cerebral insufficiencies. Its hydrolysis product, cis-apovincaminic acid, represents an example for ampholytes, in which the zwitterionic form occurs in several orders of magnitude higher concentration than its non-charged protonation isomer. The contribution of the zwitterionic microspecies of cis-apovincaminic acid is about 8 times more important, than that of the non-charged form to passive membrane-penetration and other lipophilicity-related processes (Fig.4)

The overwhelming dominance of the zwitterionic form of thyroxine, the vitally important thyroid hormone, ensures that its contribution to the overall lipophilicity exceeds 14,500 times that of the non-charged one (Fig.5).

As a result of our studies, there is clear-cut evidence that passive diffusion into lipophilic media is not necessarily predominated by the non-charged species, contrary to the widespread misbelief.

The first experimentally determined conformer-specific partition coefficients showed that conformers are greatly different in partition properties. The partition properties of the clenbuterol conformers (Fig.6) could be interpreted in terms of intramolecular interactions between the vicinal polar sites and the solvent-accessibility of the groups. The conformers can be put into order of their membrane-influx and -outflow propensities (Fig.7). 